\title{
LITERATURĂ
}

\section{Problema corporalităţii în proza lui Max Blecher şi a lui Bruno Schulz din perspectiva antropologiei filosofice}

\author{
The problem of corporality in Max Blecher's \\ and Bruno Schulz's prose from the perspective \\ of philosophical anthropology
}

\author{
Justyna Teodorowicz \\ Uniwersytet im. Adama Mickiewicza w Poznaniu \\ jus@amu.edu.pl
}

\begin{abstract}
The article discusses the problem of corporality in Max Blecher's novels and Bruno Schulz's short stories from the perspective of philosophical anthropology. The motifs of body and matter, predominant in both authors' work, are a means of presenting the place of man in the universe and dealing with such questions as identity or ontology. Through the use of somatic metaphors all the elements of the fictional world are anthropomorphised or given human characteristics, which leads to the lack of hierarchy. Whereas philosophical anthropology presents humans as active and rational beings, Blecher and Schulz stress the illusion of man's individuality and question his privileged position in the world.
\end{abstract}

Keywords: Max Blecher, Bruno Schulz, body, matter, identity, philosophical anthropology

Numele lui Max Blecher a fost pronunţat de critica literară românească în legătură cu cel al lui Bruno Schulz încă din anii şaizeci ai secolului al XX-lea, înainte ca opera scriitorului polonez să fie accesibilă publicului cititor din România (prima traducere românească a Prăvăliilor de scorţişoară a apărut în 1976). Într-o carte consacrată literaturii române interbelice, Ovid S. Crohmălniceanu (1967) a identificat câteva puncte de convergenţă între operele celor doi scriitori, mai ales 
„facultatea de a se instala în nenorocire” (p. 544) şi „preferinţa pentru lucrurile devalorizate şi comune" (p. 546). Critica românească de mai târziu a văzut şi alte înrudiri între Schulz şi Blecher, cum ar fi o similară „perspectiv[ă] asupra lumii” (Manolescu, 1998, p. 560), prezenţa unor elemente de imaginar comune (Ţepoşu, 1983) sau tendinţa spre absurd (Mironescu, 2006). Dumitru Tucan (2014) observă la cei doi autori o „efervescenţă lirică a naraţiunii” (p. 352), o „densificare narativă” (p. 353) şi o „dominantă obsesie a insolitului” (p. 355), pe când Christian Moraru (2018) îi plasează pe amândoi în „reţeaua” lui Franz Kafka.

În Polonia, problema convergenţelor dintre Schulz şi Blecher 1-a preocupat pe Zdzisław Hryhorowicz, care a identificat în opera celor doi scriitori nişte înrudiri spaţiale (Hryhorowicz, 2009), tendinţa spre mitizare şi o criză ontologică (Hryhorowicz, 2015). Błażej Szymankiewicz (2016), într-un studiu comparativ, semnalează onirismul, problema bolii şi a morţii, accentul pus pe corporalitate, conceptul „identităţii extatice" şi al spaţiilor mitizate. În fine, Subocz şi Staroń (2017), căutând paralele între opera schulziană şi cea blecheriană, analizează esenţa genialităţii copilăriei, problema melancoliei şi a doliului, poetica visului ca una dintre tehnicile narative dominatoare şi mitizarea universului.

În opinia noastră, una dintre temele cele mai importante atât în opera lui Bruno Schulz, cât şi în cea a lui Max Blecher este corporalitatea, care trebuie privită nu doar ca un motiv literar, ci într-un context mult mai larg.

Żaneta Nalewajk (2010) scrie:

Prezența problematicii corporalităţ̧i în opera (...) lui Schulz, predilecţia pentru „a vorbi despre corp" şi ,a scrie cu corpul” sunt semnificative; nu au un caracter pur ornamental sau accidental. Din contra, acestea sunt punctul de plecare pentru formularea unei viziuni personale a omului şi a realităţii, legate de o concepţie a culturii şi de înţelegerea identităţii, a valorilor sau a cunoaşterii. Cred că în paginile operei în proză a acestor autori, prin actualizarea categoriei corpului se manifestă şi îşi găsesc expresia artistică desăvârşită cele mai importante probleme ale epocii moderniste (p. 12 , trad. noastră) ${ }^{1}$.

Această caracteristică a prozei schulziene este foarte adecvată şi în cazul romanelor lui Blecher, ceea ce a fost remarcat şi de alţi cercetători (Szymankiewicz, 2016). Specificitatea textelor ambilor scriitori constă, printre altele, în faptul că ele abordează unele probleme legate de existenţa omului cu ajutorul mijloacelor artistice. De aceea, problema corporalităţii poate fi tratată drept o categorie filosofică. Nici în cazul lui Schulz, nici în cel al lui Blecher nu poate fi vorba de un discurs

\footnotetext{
${ }^{1}$ [Obecność problematyki cielesności w utworach (...) Schulza, predylekcja do „mówienia o ciele” i „pisania ciałem” są znaczące; nie mają charakteru czysto ornamentacyjnego czy przypadkowego. Przeciwnie, to punkt wyjścia do sformułowania autorskiej wizji człowieka i rzeczywistości, powiązanej z koncepcją kultury, rozumieniem tożsamości, wartości czy wreszcie poznania. Uważam, że na kartach dzieł prozatorskich tych twórców za pośrednictwem aktualizacji kategorii ciała manifestują się oraz znajdują artystycznie najdoskonalszy wyraz kluczowe problemy epoki modernizmu.]
} 
filosofic propriu-zis, întrucât scriitorii nu întreprind o polemică deschisă cu anumite atitudini filosofice. În schimb, amândoi îi oferă cititorului propriile reflecţii şi interpretări privitoare la marile categorii ale gândirii umane, exprimate prin intermediul unei poetici specifice, care este legată de corporalitate. Analiza tuturor aspectelor filosofice ale dimensiunii corporale a operei celor doi autori ar cere un studiu mult mai amplu, de aceea, în prezentul articol, ne vom concentra pe raportarea ei la ideile principale ale antropologiei filosofice. Pentru cercetările noastre am ales povestirile lui Bruno Schulz şi romanele lui Max Blecher Întâmplări în irealitatea imediată şi Vizuina luminată. Ne referim şi la corespondenţa lui Schulz, considerând-o a fi un autocomentariu preţios.

Aleksandra Ubertowska (2001), într-un studiu consacrat retoricii corporale în opera lui Schulz, vorbeşte despre somatizarea universului de către scriitorul polonez. Acest termen caracterizează perfect şi romanele prozatorului român.

Somatizarea realităţii în Întâmplări în irealitatea imediată este legată, în primul rând, de experienţele protagonistului, de trăirile lui interioare. Este vorba, deci, de somatizare înţeleasă în sensul general al termenului, adică apariţia unor simptome fizice (dureri, greaţă, etc.) drept o manifestare a unui stres psihologic. Ceea ce experimentează eroul lui Blecher depăşeşte, totuşi, afecţiunile „comune”. Aceasta se poate observa chiar în prima scenă a romanului, în care protagonistul se simte, pentru o clipă, lipsit de identitate şi caută s-o regăsească:

Teribila întrebare „cine anume sunt” trăieşte atunci în mine ca un corp în întregime nou, crescut în mine cu o piele şi nişte organe ce-mi sunt complet necunoscute. Rezolvarea ei este cerută de o luciditate mai profundă şi mai esenţială decât a creierului. Tot ce e capabil să se agite în corpul meu, se agită, se zbate şi se revoltă mai puternic şi mai elementar decât în viaţa cotidiană. Totul imploră o soluţie (Blecher, 1936, p. 1).

Criza identităţii capătă, astfel, o dimensiune fizică, corporală. Nesiguranţa eroului, îndoiala privitoare la existenţa lui este resimţită ca prezenţa unui organism străin în corpul lui. În plus, răspunsul la întrebarea „cine sunt” nu poate fi dat decât pe planul senzorial, fiind solicitat tot de corp care, după narator, este mult mai lucid decât mintea. Dorinţa de a găsi acest răspuns se manifestă printr-o agitaţie interioară, dar nu a sufletului, ci a corpului.

La Schulz, somatizarea atinge materia înconjurătoare. „Nu există materie moartă - citim în Tratat despre manechine sau cartea a doua a genului - Starea de repaus este doar o aparenţă, în spatele căreia se ascund formele necunoscute ale vieţii. Gama acestor forme este infinită, iar variaţiile şi nuanţele - inepuizabile" (Schulz, 1976 , p. 48) ${ }^{2}$. Acest fragment poate fi citit ca un metatext, întrucât ideile exprimate de Jakub îşi găsesc reflectarea în metaforica prezentă şi în alte povestiri ale lui

\footnotetext{
${ }^{2}$ Toate citatele din povestirile lui Bruno Schulz au fost preluate din aceeaşi ediţie. Pentru mai multă claritate, în continuare vom indica în text doar numărul paginii.
} 
Schulz, a cărei trăsătură caracteristică este supunerea obiectelor, a spaţiilor şi chiar a noţiunilor abstracte unui proces de animizare şi antropomorfizare. Acest procedeu se traduce prin descrierea acestora cu ajutorul unui lexic împrumutat din domeniul anatomiei şi al fiziologiei. În povestirea August naratorul vorbeşte despre „pătratele de lumină visându-şi visul lor pasionant pe podea” (p. 9), despre „fizionomia destinului şi a vieţii” (p. 9) şi ,,întreaga arşiţă a zilei” care „respira în storurile uşor unduite de visarea după-amiezii” (p. 9). În proza schulziană ferestrele, ,orbite de strălucirea pieţii pustii, dormeau” (p. 10), grădina se ,întoarce în somn de pe o parte pe alta” (p. 12), pălămida este „fudulă de carnea ei neruşinată” (p. 14), buruienile „,salivează otravă sclipitoare” (p. 14), iar floarea-soarelui, „suferind de elefantiazis”, se încovoaie „sub greutatea monstruosului trup” (pp. 11-12). Casele din Noaptea marelui sezon „se îmbujorau” (p. 127), duşumeaua ,îşi număra la lumină pătratele lucitoare (...) care vorbeau între ele trosnind şi îşi răspundeau ici şi colo" (p. 130), iar stofele „Zăceau tăcute, mute" şi „îşi aruncau de-a lungul pereţilor priviri”" (p. 130). În fragmentul intitulat Viforniţa găsim imaginea sugestivă a unor case care „se ridicau ţipînd, cuprinse de paroxism” (p. 117), pe când „fagii uriaşi din jurul bisericii stăteau cu braţele ridicate (...) şi ţipau, ţipau...” (p. 117). În Păsările metafora „plămînii negri ai viforelor” (p. 30) stârneşte asociaţii cu efortul necesar pentru susţinerea vieţii.

În toate exemplele citate mai sus avem de-a face cu desfiinţarea limitelor dintre animat şi inanimat. Acţiunile rezervate, de obicei, omului devin, astfel, accesibile atât lumii vegetale, cât şi obiectelor şi spaţiilor.

Romanul lui Blecher Întâmplări în irealitatea imediată abundă, de asemenea, în proiecţii şi descrieri animizante şi antropomorfizante ale decorului. Obiectele seamănă cu oamenii ca aspect fizic şi din punct de vedere fiziologic. Casele au ,acoperişul tras peste ochi, strângând din maxilare ca nişte boxeuri” (p. 30), iar când uşile lor sunt deschise, ele ,[aspiră] aer” (p. 29). În casa familiei Weber ,[v]itrinele cu geamuri de sticlă se clătinau uşor (...), parcă ar fi clănţănit din dinţi” (p. 19), iar pe podeaua de lemn se ivesc „riduri lungi de murdărie” (p. 40). În altă parte citim despre întunericul care ,aspira lumina ca o gură rece, avidă şi beantă” (p. 10).

Deseori, naratorul romanului are tendinţa să perceapă în elemente ale naturii semne de boală; în mintea lui se nasc asociaţii cu ţesuturi alterate, corpuri atinse de leziuni. Astfel, protagonistul observă că spaţiul este umplut „cu abcesele închistate ale pietrelor, cu scorburile rănite ale copacilor..." (p. 27). Norii, spre apus de soare, devin „sângeroşi şi purulenţi” (p. 31), iar în tăietura sfeclelor apare „sângele roşu şi întunecat al pământului” (p. 30). Crăpăturile sculptate de ploaie în malul înalt al râului sunt caracterizate de eroul blecherian drept ,hidoase ca nişte plăgi rău cicatrizate”, părând a fi ,adevărate zdrenţe din carnea lutului, răni oribile şi beante” (p. 2). Această predilecţie pentru imagistica legată de un corp bolnav poate fi o proiecţie a biografiei autorului, biografie stigmatizată de suferinţa fizică. Cum 
scrie Beata Przymuszała (2017), antropomorfizarea constituie, uneori, un mod reflex de a vedea lumea înconjurătoare prin prisma experienţelor trăite.

Acest procedeu de antropomorfizare a universului imaginar schulzian şi blecherian nu constă doar în dotarea elementelor lui cu nişte caracteristici fizice sau fiziologice umane. Obiectele sunt, în plus, capabile de procese intelectuale mai complicate. Atât la Schulz, cât şi la Blecher fiecare părticică a realităţii are trăsături psihice, spirituale, are conştiinţă de sine. Sursa vieţii este, deci, situată în materie, şi nu în afara ei. Această caracteristică a universului material se manifestă, deseori, prin adoptarea unei atitudini răutăcioase faţă de om. Povestitorul Întâmplărilor ... are impresia că toate lucrurile, chiar şi cele mai obişnuite, sunt capabile de perfidie, de maliţiozitate: „Priveam cărţile legate în dulapul cu geam şi în imobilitatea lor remarcam, nu ştiu cum, un aer perfid de tăinuire şi complicitate. Obiectele din jurul meu nu renunţau niciodată la o atitudine secretă...” (p. 3).

Unul dintre personajele lui Schulz, eroul povestirii Domnul Carol se simte, la rândul lui, observat cu duşmănie tăcută şi neacceptat de propria lui locuinţă:

Casa, pustie şi părăginită, nu-1 recunoştea, mobila şi pereţii îl urmăreau cu reprobare. Cînd intra în liniştea lor se simţea ca un intrus (...). Deschizîndu-şi propriile sertare, avea sentimentul unui hoţ şi umbla, fără să vrea, în vîrful degetelor, temîndu-se să nu stîrnească ecoul zgomotos, ce aştepta iritat cel mai mic motiv ca să izbucnească (p. 76).

La amândoi scriitorii materia, asemenea omului, este dotată cu o memorie în care îşi păstrează amintirile din vremuri trecute, închide portrete ale oamenilor, înregistrează întâmplări, impresii, ambianţe, bucurii şi nenorociri omeneşti. La Schulz, „locuinţele vechi, saturate de emanaţiile numeroaselor vietăţi şi întîmplări, cu aerul lor viciat, bogat în ingrediente specifice visurilor umane - ruinele cu humusul amintirilor şi dorurilor, al plictiselilor sterile" (p. 57) absorb trăirile oamenilor pentru a le dezvălui mai târziu într-un act de autoexprimare:

[Tata] simţea, fără să se uite, că spaţiul îl înfăşoară în desişul pulsant al tapetelor, înţesat cu şoapte, cu şuierat şi sîsiit. Auzea, fără să privească, această conspiraţie plină de semne tainice, de ochiade, de urechi ce creşteau printre flori şi ascultau, de guri întunecate şi zîmbitoare (p. 23).

La Blecher, unul dintre spaţiile prin care transpar întâmplările şi persoanele din trecut este etajul casei Weber:

Între fotografii şi obiectele din vitrine - fructiera de sticlă roz cu marginile în volute, poşetele de catifea în care nu era nimic alta (sic!) decât mătasea roasă de molii, diverse obiecte cu monograme necunoscute - între toate acestea domnea un aer de perfectă înţelegere ca un fel de viaţă proprie a lor, identică vieţii de odinioară când fotografiile de pildă corespundeau unor persoane ce se mişcau şi trăiau, şi când scrisorile erau scrise de calde mâini adevărate - însă o viaţă redusă la o scară mai mică, într-un spaţiu mai 
restrâns, în limita scrisorilor şi a fotografiilor, ca într-un decor privit prin lentilele cele groase ale unui binoclu, decor rămas exact în toate componentele lui însă minuscul şi îndepărtat (p. 19).

Cel mai expresiv exemplu al obiectului care povesteşte istoria a ceea ce constituie este reprezentat de două stampe cu portretul lui Carol I şi al reginei Elisabeta, găsite de eroul Intâmplărilor ... în casa bunicului său:

Într-o zi făcui o descoperire uimitoare: ceea ce luam eu drept culoare ştearsă nu era altceva decât o îngrămădire de litere minuscule, descifrabile numai cu lupa. În tot desenul nu era o singură trăsătură de creion ori de pensulă; totul era o alăturare de cuvinte în care se povestea istoria vieţii regelui şi a reginei (p. 20).

În cele două tablouri cu o înfăţişare a cuplului regal textul se transformă literal în imagine, constituind o „metaforă corporală a scriiturii” (Sora, 2008, p. 190).

Tezele privitoare la materie, exprimate de Jakub în Tratat despre manechine sau cartea a doua a genului, sunt convergente cu un fel de credo filosofic al Prăvăliilor de scorţişoară cuprins într-o scrisoare a lui Bruno Schulz către Stanisław Ignacy Witkiewicz:

Substanţa acelei realităţi este într-o stare de perpetuă fermentare, germinare, viaţă latentă. $\mathrm{Nu}$ există obiecte moarte, dure, limitate. Totul se difuzează peste graniţele sale, durează doar o clipă într-o formă pentru a o părăsi cu prima ocazie. În obiceiurile, în modurile de a fi ale acestei realităţi se manifestă un fel de principiu - cel al panmascaradei. Realitatea ia anumite forme numai pentru aparenţă, numai în glumă, în joacă. Cineva este om, altcineva gândac de bucătărie, dar această formă nu atinge fondul, este doar un rol acceptat pentru o clipă, doar o epidermă care va fi imediat lepădată. Este aici statuat un monism extrem al substanţei, pentru care obiectele particulare sunt doar nişte măşti. Viaţa substanţei constă în epuizarea unor nenumărate măşti. Această peregrinare a formelor este esenţa vieții (Schulz, 1998, pp. 476-477, trad. noastră) ${ }^{3}$.

Monismul, despre care pomeneşte Bruno Schulz în fragmentul citat, admite uniformitatea substanţei supuse unui singur principiu - cel al metamorfozei. Fiinţele particulare se nasc dintr-o materie primă, care apoi le absorb din nou pentru a da naştere altor forme ale vieţii. Forţele creatoare ale naturii sunt inepuizabile, dar

\footnotetext{
${ }^{3}$ [Substancja tamtejszej rzeczywistości jest w stanie nieustannej fermentacji, kiełkowania, utajonego życia. Nie ma przedmiotów martwych, twardych, ograniczonych. Wszystko dyfunduje poza swoje granice, trwa tylko na chwilę w pewnym kształcie, ażeby go przy pierwszej sposobności opuścić. W zwyczajach, w sposobach bycia tej rzeczywistości przejawia się pewnego rodzaju zasada - panmaskarady. Rzeczywistość przybiera pewne kształty tylko dla pozoru, dla żartu, dla zabawy. Ktoś jest człowiekiem, a ktoś karakonem, ale ten kształt nie sięga istoty, jest tylko rolą na chwilę przyjętą, tylko naskórkiem, który za chwilę zostanie zrzucony. Statuowany tu jest pewien skrajny monizm substancji, dla której poszczególne przedmioty są jedynie maskami. Życie substancji polega na zużywaniu niezmiernej ilości masek. Ta wędrówka form jest istotą życia.]
} 
niciuna dintre creaţiile ei nu este durabilă. Omul devine, astfel, doar una dintre incarnările posibile ale materiei, fiind supus, şi el, unor constante schimbări. În opera lui Schulz orice se poate transforma în orice: Tatăl într-un gândac de bucătărie, câinele ţinut în lanţ într-un om, copiii în cocoşi, calul într-un cal mic de lemn. Astfel, gama gradelor de realitate din opera lui Schulz nu cunoaşte limite, imaginaţia lui fiind una dintre cele mai strălucitoare „imaginaţii materiale” din literatura poloneză (Chwin, 1985). Scriitorul construieşte diferite semi-realităţi, sferturi de realităţi, lumi „agăţate de metafore” (Stala, 1995, p. 225). Aceste metamorfoze ale persoanelor, ale spaţiilor, ale obiectelor curg fluent. Deplasarea între cele două lumi - cea a fantasticului şi cea a obişnuitului - se face imperceptibil, natural, fără semnalarea modificării punctului de vedere. Această trăsătură a poeticii schulziene adânceşte efectul înstrăinării.

Aceeaşi jonglare cu gradul de realitate (Stala, 1995, p. 225) caracterizează universul romanelor lui Max Blecher. Şi aici avem de-a face cu trecerea spontană de la o lume la alta, cu schimbarea naturală a opticii. Delimitarea acestor lumi este cu atât mai grea, cu cât însuşi eroul blecherian nu face distincţie între ele: „nu este nicio diferenţă între lumea exterioară şi cea a imaginilor mintale" (Blecher, 1971, p. 7). La Blecher, ca la Schulz, datorită puterii creatoare a comparaţiilor folosite de narator, înaintea ochilor cititorului se desfăşoară o suită de imagini diverse. O scenă banală, luată din viaţa cotidiană a locuitorilor capitalei, se transformă într-un tablou suprarealist:

Am văzut în anumit fel piaţeta din faţa poştei din Bucureşti (...). Şi piaţeta, acum, îmi apare când complet albă, când complet roşie, albă în zilele de soare când stau, de exemplu, afară la soare pe terasa mea mărginită de grădină, şi roşie când seara, obosit, închid ochii. Îmi place chiar mai mult poate acest aspect al ei sângeros. Când piaţeta e roşie, firele de mustaţă ale domnului cu baston sunt ca firişoarele acelea de hârtie colorată cu care se învelesc îndeobşte obiectele fragile, vesta şi haina îl îmbracă elegant ca nişte carapace de rac fiert, bastonul în mână e ca o bomboană din cele ieftine pe care le sug copiii, geamurile la case, ca acadelele ce le fabrică turcii ambulanţi vânzători de bragă, frunzele şi iarba sunt stropite cu sânge, un băiat care goleşte un lichid dintr-o sticlă, nu varsă apă, ci sânge - şi dinţii oamenilor sunt din coraliu fin, degetele de porfir şi urechile din cartilagiu purpuriu. Când măturătorul curăță strada cu măturoiul lui cu fire roşii ca mustăţile de homard (sic!), în urma lui se ridică un praf roşu ca praful de cărămidă. Şi cerul deasupra este roşu şi strălucitor ca o imensă cupă de cristal colorat... (Blecher, 1971, pp. 10-11).

Schimbarea culorii, unificarea cromatică a obiectelor şi a persoanelor din piaţă aduce proprietăţi noi materiei din care acestea sunt alcătuite. Întreaga scenă capătă un caracter oniric, deşi naratorul subliniază faptul că este treaz şi conştient de ceea ce vede. Pentru el visul şi realitatea sunt două spaţii echivalente. Singura instanţă este imaginaţia lui nelimitată. Orice detaliu poate deveni un prilej de a sesiza o altă 
faţetă a realităţii, a substanţei. Acolo unde ceilalţi văd doar obiecte obişnuite, el observă ceva nou, accesibil numai percepţiei lui. Astfel, o eşarfă se poate transforma într-un buchet de flori, ca în scena următoare din Întâmplări...:

Văzui deodată pe o etajeră un buchet mare de flori într-un vas. (...)

- Ce frumoase sunt florile acelea, spusei Eddei.

- Care flori?

- Cele de colo, de pe etajeră...

- Care flori?

- Daliile acelea roşii atât de frumoase...

- Care dalii?

- Cum asta, ...,,care dalii”?

Mă ridicai şi mă repezii la etajeră. Aruncată pe o grămadă de cărţi zăcea o eşarfă roşie (p. 37).

La ambii scriitori se poate vorbi despre unificarea, identificarea personajelor cu lumea materială. În proza lui Schulz ideea aceasta este redată prin tendinţa lor de a pătrunde în substanţ̧a animată a obiectelor, de a se integra cu ea:

La această oră timpurie, tata se trezea şi cobora scările, încărcat de registre, ca să deschidă prăvălia de la parterul casei. O clipă rămînea nemişcat în poartă, stăvilind cu ochii închişi puternicul atac al focului solar. Peretele însorit al casei îl atrăgea blînd în suprafaţa sa plată, nivelată plăcut, netezită pînă la dispariţie. Şi pentru o clipă devenea şi el un tată plat, imprimat în faţadă, şi îşi simţea mîinile răsfirate, tremurătoare şi calde, contopindu-se netede în structura aurie a faţadei (pp. 298-299).

În scena de mai sus Tatăl pierde pentru un timp o parte din natura lui omenească, devine o fiinţă hibridă, a cărei identitate este greu de stabilit. Ubertowska (2001) vorbeşte despre „un corp spaţializat” (p. 245) care, fiind un corp transcendent, depăşeşte graniţa persoanei şi creează o nouă realitate, eterogenă din punct de vedere ontologic. Aceeaşi strategie de „prelungire aproape organică a corpului” (Tucan, 2014, p. 354) în lume se poate observa şi în proza lui Blecher. Naratorul romanului Întâmplări în irealitatea imediată are deseori senzaţia dezintegrării corpului său care pătrunde în structura omogenă a realităţii materiale:

Între mine şi lume nu exista nici o despărţire. Tot ce mă înconjura mă invada din cap până în picioare, ca şi cum pielea mea ar fi fost ciuruită. Atenţia, foarte distrată de altfel, cu care priveam în jurul meu nu era un simplu act de voință. Lumea îşi prelungea în mine în mod natural toate tentaculele; eram străbătut de miile de braţe ale hidrei (p. 4).

Fragmentul de mai sus exprimă ideea de contopire a protagonistului cu universul. Eroul Întâmplărilor ... nu vede nicio diferenţă între el ca fiinţă umană şi materie; dimpotrivă, este convins că între oameni şi obiecte există o relaţie de egalitate: „un fel de echitate (...) între mine şi lume (...) mă cufunda încă mai iremediabil în uni- 
formitatea materiei brute” (p. 4). Mai ales în timpul „crizelor” naratorul romanului se simte dominat, chiar absorbit de spaţiul antropomorfizat:

...obiectele erau apucate de o adevărată frenezie de libertate. Ele deveneau independente unele faţă de altele, dar de o independenţă ce nu însemna numai o simplă izolare a lor ci şi extatică exaltare. Entuziasmul lor de a exista într-o nouă aureolă mă cuprindea şi pe mine: aderenţe puternice mă legau de ele, cu anastomoze invizibile ce făceau din mine un obiect al odăii la fel cu celelalte, în acelaşi mod în care un organ grefat pe carne vie, prin schimburi subtile de substanțe, se integrează trupului necunoscut (p. 3).

În fragmentul citat graniţa dintre subiectul uman şi obiectul percepţiei sale se estompează. Natura moartă, adică încăperea cu tot decorul, devine o fiinţăa, este comparată cu un ,trup necunoscut”, la care eroul, redus la un organ grefat pe acesta, trebuie să se adapteze.

Materia îl invadează pe naratorul Întâmplărilor ..., care se simte pierdut în mulţimea copleşitoare de forme ale ei:

În jurul meu materia dură şi imobilă mă înconjura din toate părţile - aici în formă de bile şi de sculpturi - în stradă în formă de copaci, de case, şi de pietre; imensă şi zadarnică, închizându-mă în ea din cap şi până în picioare, în orice sens mă gândeam, materia mă înconjura, începând de la hainele mele, până la izvoarele din păduri, trecând prin ziduri, prin copaci, prin pietre, prin sticle... (p. 27).

În opera lui Blecher ideea monismului substanţei este exemplificată în cel mai expresiv mod în scena contopirii eroului Întâmplărilor ... cu pământul:

...în faţa mea se întindea până departe noroiul cald şi moale. (...) Întâi ezitai, în mine mai luptau cu forţe de gladiatori muribunzi ultimele urme de educaţie. (...) Intrai în noroi mai întâi cu un picior, apoi cu celălalt. (...) Eram acum crescut din noroi, una cu dânsul, ca ţâşnit din pământ. (...) Oamenii şi lucrurile ţâşniseră din chiar această baligă şi urină în care eu îmi înfundam nişte ghete foarte concrete (p. 30).

În scena de mai sus universul materiei pure este opus universului lucrurilor create de om, reprezentat de ghetele „foarte concrete" ale eroului, care constituie o linie de demarcaţie simbolică între cele două realităţi (Subocz şi Staroń, 2017). Naratorul se simte scindat între tentaţia de a intra în noroi, „masa aceasta curată şi sublimă" (p. 30), şi regulile de comportament proprii unui om civilizat. În fine, cuprins de un sentiment neaşteptat de bucurie, renunţă la acestea din urmă pentru a deveni unul cu materia elementară a pământului. Se realizează, astfel, ,„[r]eintegrarea în ritmurile cosmice, abolirea conştiinţei individuale, revelaţia consubstanţialităţii şi compenetrabilităţii regnurilor” (Patraş, 2000):

În jurul meu se întindea maidanul plin de noroi... Aceasta era carnea mea autentică, jupuită de haine, jupuită de piele, jupuită de muşchi, jupuită până la noroi. Umezeala lui 
elastică şi mirosul lui crud mă primeau până în adâncuri pentru că le aparţineam până în adâncime (p. 30).

După cum se pare, ,corpul, împreună cu psihicul legat de el, este doar o ţâşnire momentană din adâncul existenţei, (...) ceea ce este general precede ceea ce este particular; ceva asemănător cu elementul cosmic dionisiac care anulează principiul apolinic de individuare" (Skarga, 1997, p. 216, trad. noastră) ${ }^{4}$.

Dintre personajele lui Schulz, Tatăl pare a fi singurul care părăseşte în mod conştient forma sa de individ, respinge teama de a-şi pierde identitatea şi începe să dispreţuiască principium individuationis ca principiu uman primordial (Schulz, 1998, p. 356). Manifestă, de asemenea, un interes deosebit pentru animale, pe care le tratează ca pe forme înrudite ale vieţii. Naratorul povestirilor este, la rândul lui, fascinat de căţelul Nimrod, în care vede o sursă de cunoştinţe despre om: „Animalele! Ţelul curiozităţii nesăţioase, exemplificarea tainei vieţii, create parcă pentru a arăta omului omul..." (p. 63). Nimrod, ca şi alte incarnări ale materiei, este dotat cu o memorie a trupului:

...începe să înţeleagă că ceea ce i se propune este, în fond, cu toate aparenţele noutăţii, ceva ce a mai fost, a mai fost de multe ori, de nesfîrşit de multe ori. Trupul lui cunoaşte situaţii, impresii şi obiecte. (...) În faţa fiecărei situaţii noi se cufundă în memoria sa, în memoria adîncă a trupului, şi caută pe dibuite, febril - şi se întîmplă să găsească în el reacţii corespunzătoare: înţelepciunea generaţiilor, depozitată în plasma lui, în nervii lui. Găseşte fapte, hotărîri, despre care nici nu ştia că se maturizaseră în el, că aşteptau să iasă la lumină (p. 65).

Astfel, prin intermediul corporalităţii se manifestă un fond preindividual, necontrolat de conştiinţă. Cunoştinţele corpului constituie o cunoaştere ontologică primordială, preintelectuală (Drwięga, 2005).

În proza lui Schulz şi a lui Blecher corporalitatea determină vădit specificitatea construcţiei personajelor literare. Cum demonstrează conţinutul textelor în discuţie, tocmai corpul este unul dintre factorii decisivi în formarea identităţii eroilor, influenţând considerabil şi calitatea relaţiilor lor sociale. Categoria corporalităţii redă atât multidimensionalitatea, cât şi complexitatea condiţiei umane, face posibilă dezvăluirea experienţelor fundamentale ale omului. Construindu-şi personajele literare, scriitorii discutaţi încearcă să înţeleagă cine este omul şi care este poziţia lui faţă de natură şi cultură. Caracterul problemelor pe care le este axată opera o plasează în contextul antropologic, dat fiind că literatura este locul dezvăluirii firii omeneşti, că datorită ei omul ajunge la esenţa lui (Markowski, 2007). Întrebările la care Schulz

\footnotetext{
${ }^{4}$ [ciało wraz ze związanym z nim psychizmem jest tylko chwilowym wytryskiem z głębi bytu, (...) to, co ogólne, wyprzedza to, co poszczególne; coś na wzór owego Dionizyjskiego pierwiastka kosmicznego rozbijającego Apollińską zasadę indywiduacji.]
} 
şi Blecher caută răspunsul sunt aceleaşi pe care şi le pune antropologia filosofică. De aceea suntem de acord cu Żaneta Nalewajk (2010) care propune o raportare a „antropologiei literare” (p. 152) a lui Bruno Schulz (înţeleasă ca o concepţie a personajului literar) la constatările acestei discipline. Credem că şi personajele create de Max Blecher pot fi discutate în relaţie cu moştenirea antropologiei filosofice. În convingerea noastră, o asemenea confruntare este cu atât mai justificată, cu cât în prim-planul preocupărilor disciplinei respective se află corporalitatea omului (Czerniak, 2004).

Antropologia filosofică ca disciplină autonomă s-a format în anii douăzeci ai secolului al XX-lea. În 1928 au apărut două opere importante în această privinţă: cea a lui Max Scheler intitulată Poziţia omului în cosmos şi studiul lui Helmuth Plessner Die Stuffen des Organischen und der Mensch (Treptele naturii organice şi omul). Alături de cei doi autori, printre clasicii antropologiei filosofice se numără şi Arnold Gehlen, a cărui principală operă este Der Mensch. Seine Natur und seine Stellung in der Welt (Omul. Natura şi poziţia lui în lume, 1940).

Scheler (2003), în lucrarea pomenită mai sus, scria:

...avem o antropologie naturalist ştiinţifică, una filosofică şi una teologică ce nu ţin cont una de alta - o idee unitară despre om însă nu avem. (...) [î]n nicio altă epocă a istoriei, omul nu a devenit atât de problematic pentru el însuşi ca în prezent (p. 10).

Acest statut neclar al omului, cum subliniază Marek Drwięga (2013), era rezultatul mai multor factori. În primul rând, sfârşitul secolului al XIX-lea şi începutul secolului al XX-lea au adus o cotitură în modul de a gândi, ca urmare a unor schimbări sociale şi politice, precum şi a descoperirilor ştiinţifice. Se admite că dezvoltarea ştiinţei în general a cauzat, în mare măsură, o criză a gândirii despre om şi poziţia sa în lume. În această privinţă, teoria lui Darwin a jucat un rol considerabil. Omul a încetat să fie privit drept coroana creaţiei şi a fost situat printre alte specii în procesul complex al evoluţiei. În al doilea rând, din secolul al XIX-lea a început să crească conştiinţa istorică, ceea ce a adus o relativizare a valorilor religioase, morale şi culturale, tratate până atunci ca un component constant şi neschimbător al firii umane. Un moment hotărâtor 1-a constituit dezvoltarea cercetărilor asupra conştiinţei. Unele şcoli au acceptat relativitatea şi caracterul secundar al conştiinţei faţă de alţi factori, mai primitivi.

Toate aceste tendinţe, pozitive din punctul de vedere al ştiinţei, s-au dovedit a fi problematice în ceea ce priveşte înţelegerea omului care a pierdut, într-un sens, locul său în lume. De aici şi necesitatea de a crea o disciplină nouă, o antropologie filosofică, care „cuprinde esenţa omului şi poziţia sa specială în relaţie cu fiinţele imediat apropiate, adică plantele şi animalele" (Şovrea, 2012, p. 175).

Conform clasicilor antropologiei filosofice, din punct de vedere biologic nu există o diferenţă de tip ierarhic între oameni şi animale. Altfel spus, omul nu este 
altceva decât un animal, deci fundamentele poziţiei lui privilegiate în lume nu pot fi căutate în natură. După Scheler (2003), elementul definitoriu al omului este spiritul, datorită căruia acesta devine „o fiinţă superioară, atât lui însuşi ca fiinţă vie, cât şi lumii” (p. 50). Doar omul are capacitatea de a face atât din lucruri, cât şi din el însuşi un obiect al cunoaşterii. Plessner explică poziţia specială a omului prin capacitatea acestuia de a se ex-centriza, adică de a se poziţiona faţă de sine însuşi, ceea ce face posibilă afirmarea realităţii trupului şi a sufletului său. Mai departe, filosoful subliniază că existenţa omului este dependentă de activitatea lui. Pe când animalul trăieşte în mediul natural, omul (incomplet de la natură) creează un alt mediu, unul artificial, fiind forţat „să îşi conducă viaţa şi să îşi construiască existenţa” (Şovrea, 2012, p. 180). În plus, conştiinţa nimicniciei lucrurilor îi dă omului ,sentimentul unicităţii şi individualităţii sale în lume" (Şovrea, 2012, p. 182). Gehlen (inspirat de Johann von Herder) vede în om, la nivel biologic, o fiinţă deficitară în raport cu alte animale. Omul nu este specializat pentru a se apăra contra duşmanilor naturali, nu se adaptează într-un mediu specific. Faptul că este capabil să trăiască oriunde pe pământ, în ciuda lipsurilor sale biologice, se explică, în concepţia lui Gehlen, prin conceptul de fiinţă culturală. Tocmai deficienţele omului îl forţează să îşi creeze un spaţiu cultural care să devină mediul lui natural. Astfel, „Gehlen ne propune să înţelegem omul ca fiinţă care acţionează” (Şovrea, 2012, p. 184) şi este în stare să se opună lumii (p. 183). Instrumentele cu care îşi compensează deficienţele sunt limba şi instituţiile sociale (Czerniak, 1998). În fine, omul nu cedează tuturor instinctelor ca animalele. Îşi proiectează conştient scopurile şi alege mijloacele potrivite pentru realizarea lor. Ştie să-şi planifice acţiunile (Kuderowicz, 2001).

Căutând răspunsul la întrebările privitoare la condiţia umană, la locul omului în univers şi sensul existenţei, antropologia filosofică rămâne o disciplină antropocentrică (Nalewajk, 2010).

Concepţiile despre om şi locul lui în lume care se pot deduce din opera lui Schulz şi a lui Blecher sunt bazate pe alte principii. Personajele literare create de aceşti autori nu sunt întotdeauna fiinţe raţionale. Deseori, existenţa lor seamănă cu cea a plantelor, a animalelor sau a obiectelor. În povestirea August a lui Schulz apare bătrâna Maryśka, ,palidă ca anafura şi tăcută ca o mănuşă scoasă de pe mînă” (p. 15). Personajul acesta este reificat, se transformă - prin forţa comparaţiei - întrun obiect (mănuşă) privat de elementul animizant (mână). Metafora aceasta capătă o semnificaţie specială într-un univers imaginar atât de mult antropomorfizat ca cel al lui Schulz. Naratorul lui Blecher, la rândul lui, se identifică cu propria lui fotografie, dându-ş̧i seama, totodată, de „minusurile (...) în propria persoană” (Chiriță, 2009). Semnificativ, în acest context, este rolul acordat manechinului. Atât Schulz, cât şi Blecher par a fi fascinaţi de această figură. În Tratat despre manechine sau cartea a doua a genului Jakub postulează crearea omului ,pentru a doua oară, după chipul şi asemănarea manechinului” (p. 51). Protagonistul Întâmplărilor ... crede, la rândul lui, că personajele de ceară din panopticum sunt ,singurul lucru autentic din 
lume (...), făcând parte, prin imobilitatea lor stranie şi artificială din aerul adevărat al lumii” (p. 15). Ceea ce este artificial capătă, astfel, un grad ridicat de autenticitate şi - cum putem presupune - devine mai valoros decât omul. Eroul blecherian presimte în figura de ceară a unei femei un sens ascuns, un înţeles profund, „o semnificaţie adâncă şi turburătoare pe care nimeni n-o ştia” (p. 15).

Existenţa personajelor din proza celor doi scriitori pare, deseori, lipsită de finalitate. Cititorul Străzii Crocodililor a lui Schulz are impresia „unei călătorii demente, monotone, zadarnice, a unui cortegiu de marionete. $\mathrm{O}$ atmosferă de ciudată banalitate respiră în tot decorul acesta. Mulţimea curge monoton şi, curios, o vezi întotdeauna vag, figurile trec într-o înghesuială confuză, molatică, fără să prindă contururi" (p. 102).

Aceeaşi senzaţie de monotonie şi inutilitate emană din textul Întâmplărilor ... lui Blecher:

Toate acţiunile mele cotidiene puteau fi amestecate ca un joc de cărţi, nu ţineam la nici una din ele; iresponsabilitatea oamenilor faţă de actele lor cele mai conştiente era un fapt de o evidenţă ce sărea în ochi. Ce importanţă avea că le comiteam eu sau altul, din moment ce diversitatea lumii le înghiţea în aceeaşi uniformă monotonie? (p. 15).

După cum demonstrează analizele textelor literare prezentate mai sus, în cazul amânduror scriitorilor se poate vorbi de o lipsă a ierarhiei în realitatea creată de ei, o realitate fluidă, dezorganizată. Omul este situat la acelaşi nivel cu celelalte forme ale existenţei. Chiar şi apartenenţa ontologică a eroilor la specii este neclară. Unii dintre ei funcţionează ca nişte hibrizi. Tatăl schulzian are în el şi ceva din insectă, altădată din pasăre. Medicul care prescrie chinina naratorului Întâmplărilor... este alcătuit, în parte, din „materi[e] şoricească” pe care o împrumută ,pentru exercitarea existenţei sale ilegale de $<$ om $>$ ” (p. 8). Semnificativă este şi prezenţa personajelor mutilate, schiloade, atinse de boli fizice şi mintale (la Schulz acestea sunt Tłuja, Dodo, Tatăl; la Blecher Ozzy sau nebuna oraşului). Omul schulzian şi cel blecherian sunt lipsiţi de liber-arbitru, fiind supuşi unor automatisme, unor legi ale materiei. Astfel, eroul povestirii Pensionarul, a cărui condiţie este determinată de corporalitate din ce în ce mai firavă, este luat de vânt. Există, deci, pasiv, ca obiect, nu ca subiect. Şi naratorul Intâmplărilor... este obsedat de sentimentul fatalităţii; are impresia că viaţa lui este hotărâtă, că cineva i-a scris un scenariu la care el nu mai poate aduce nicio modificare. Chiar şi cele mai mici gesturi, cele mai neînsemnate situaţii constituie pentru el o dovadă a prestabilirii sorţii lui. Când aude „Aha!... ai venit!..." de la o femeie necunoscută, care spală rufe în antreul varieteului, interpretează aceste cuvinte drept o sentinţă:

...vorbele femeii nu mi se părură chiar atât de simple: era poate în ele anunţul unei fatalităţi ce prezida la zbaterile mele şi care prin gura spălătoresei, îmi arăta că locurile aventurilor mele erau fixate dinainte şi că eram sortit să cad în ele ca în nişte curse bine întinse... (p. 27) 
Se pare că antropologia filosofică şi antropologiile literare ale lui Bruno Schulz şi lui Max Blecher au surse comune, fiind un răspuns la criza în care se afla lumea în epoca interbelică (Mironescu, 2006; Moraru, 2018). Totuşi, concluziile celor doi scriitori diferă substanţial de constatările filosofilor germani. Prin crearea personajelor dependente de legile materiei, Schulz şi Blecher expun iluzia individualităţ̧ii omului şi a poziţiei lui privilegiate în lume. Opiniile lor constituie o voce importantă în discuţia despre condiţia omului, exprimată prin intermediul literaturii care, fiind un ,mod hotărâtor de a forma realitatea culturală” (Iser, 1989, p. 283, trad. noastră) ${ }^{5}$, este identică cu existenţa.

\footnotetext{
${ }^{5}$ [a decisive means of shaping cultural reality]
} 


\section{BIBLIOGRAFIE}

Blecher, M. (1936). Întâmplări în irealitatea imediată. Extras de pe: https://drive.google. com/file/d/0BxL9M-N33roOUGx3Tm85N0NtaUU/view.

Blecher, M. (1971). Vizuina luminată. Extras de pe: https://drive.google.com/file/d/0BxL9MN33roOQ1R4MGtIeUJzV2c/view.

Chiriţă, G. (2009). Tirania obiectelor. In Observator cultural. 492. Extras de pe: https://www. observatorcultural.ro/articol/tirania-obiectelor/.

Chwin, S. (1985). Twórczość i autorytety: Bruno Schulz wobec romantycznych dylematów tworzenia. In Pamiętnik Literacki. 76 (1), pp. 69-93.

Crohmălniceanu, Ov. S. (1967). Literatura română dintre cele două războaie mondiale. I. Bucureşti: Editura Pentru Literatură.

Czerniak, S. (1998). Pomiędzy Szkołą Frankfurcką a postmodernizmem. Antropologia filozoficzna Gernota Böhmego na tle klasycznych stanowisk antropologii filozoficznej XX wieku. In G. Böhme. Antropologia filozoficzna. Ujęcie pragmatyczne (P. Domański, trad.). Warszawa: Wydawnictwo IFiS PAN (Textul original publicat 1985), pp. VII-XLVII.

Czerniak, S. (2004). Wstęp. Niemiecka antropologia filozoficzna XX wieku. Klasycy i wątki współczesne. In S. Czerniak, J. Rolewski (ed.). Studia z filozofii niemieckiej. Tom 4. Antropologia filozoficzna. Torun: Wydawnictwo Uniwersytetu Mikołaja Kopernika, pp. 5-22.

Drwięga, M. (2005). Ciało człowieka. Studium z antropologii filozoficznej. Kraków: Księgarnia Akademicka.

Drwięga, M. (2013). Kim jest człowiek? Studia z filozofii czlowieka. Kraków: Księgarnia Akademicka.

Hryhorowicz, Z. (2009). Bruno Schulz i Max Blecher: powinowactwa przestrzeni. In Balcanica Posnaniensia. Acta et studia. 16, pp. 21-37.

Hryhorowicz, Z. (2015). Pe marginile realităţii: Max Blecher şi Bruno Schulz. In E. Ivancu, T. Klimkowski, G. Orian (ed.). Fascinantul interbelic: idei, oameni, cărţi. Alba Iulia: Aeternitas, pp. 169-176.

Iser, W. (1989). Prospecting. From Reader Response to Literary Anthropology. Baltimore: Johns Hopkins University Press.

Kuderowicz, Z. (2001). Co frapuje, a co budzi wątpliwości w studiach Arnolda Gehlena. In A. Gehlen. W kręgu antropologii i psychologii społecznej (K. Krzemieniowa, trad.). Warszawa: Czytelnik (Textul original publicat 1986), pp. 5-19.

Manolescu, N. (1998). Arca lui Noe. Eseu despre romanul românesc. Bucureşti: 1001 Gramar.

Markowski, M.P. (2007). Antropologia i literatura. In Teksty Drugie: teoria literatury, krytyka, interpretacja. 6 (108), pp. 24-33.

Mironescu, D. (2006). În marginea absurdului: M. Blecher şi Bruno Schulz. In Transilvania. 2, pp. 11-14.

Moraru, C. (2018). Crossing the Kafka Network: Schulz, Blecher, Foer, and the Repositioning of the Human. In Caietele Echinox. Vol. 34, pp. 101-116.

Nalewajk, Ż. (2010). W stronę perspektywizmu. Problematyka cielesności w prozie Brunona Schulza i Witolda Gombrowicza. Gdańsk: słowo/obraz terytoria.

Patraş, A. (2000). În lumea lui M. Blecher. In România literară. 47.

Przymuszała, B. (2017). O nieludzkim „ludzkim” i „niezwierzęcym” zwierzęcym zachowaniu: z lektury wiersza Ludzie i hieny Frydzi Kiwatz. In Narracje o Zagładzie. 3, pp. 189-199.

Scheler, M. (2003). Poziţia omului în cosmos (V. Muscă, trad.). Piteşti: Paralela 45 (Textul original publicat 1940). 
Schulz, B. (1976). Manechinele (I. Petrică, trad.). Bucureşti: Univers (Textul original publicat 1964).

Schulz, B. (1998). Opowiadania. Wybór esejów i listów. Wrocław-Warszawa-Kraków: Zakład Narodowy im. Ossolińskich.

Skarga, B. (1997). Tożsamość i różnica. Eseje metafizyczne. Kraków: Znak.

Sora, S. (2008). Regăsirea intimităţii: corpul în proza românească interbelică şi postdecembristă. Bucureşti: Cartea Românească.

Stala, K. (1995). Na marginesach rzeczywistości. O paradoksach przedstawiania $w$ twórczości Brunona Schulza. Warszawa: IBL PAN.

Subocz, P., Staroń, I. (2017). Nadkolory i nadaromaty. Schulz, Mueller, Blecher. Lublin: Episteme.

Szymankiewicz, B. (2016). Mitomani (nie)rzeczywistości. Bruno Schulz i Max Blecher - próba porównania. In Schulz / Forum. 8, pp. 87-102. Extras de pe: https://czasopisma.bg.ug. edu.pl/index.php/schulz/article/view/2421.

Şovrea, I. (2012). Poziţia privilegiată a omului în natură. Antropologia filosofică şi relevanţa ei astăzi. In Anuarul Institutului de Istorie „, G. Bariţiu” din Cluj-Napoca, Series Humanistica. X, pp. 173-186.

Tucan, D. (2014). Receptarea literară în context comparatist: Max Blecher şi B. Schulz. In Quaestiones Romanicae, III (Papers of the International Colloquium Communication and Culture in Romance Europe) (pp. 345-356). Szeged: Jatepress.

Ţeposu, R.G. (1983). Viaţa şi opiniile personajelor. Bucureşti: Cartea Românească.

Ubertowska, A. (2001). Cielesna retoryka Brunona Schulza. In Między stowem a ciałem. Materiaty z IV Sesji Naukowej z cyklu „Świat jeden, ale nie jednolity”, Bydgoszcz, 24-26 października 2000. Bydgoszcz: Wydawnictwo Akademii Bydgoskiej im. Kazimierza Wielkiego, pp. 237-248. 